\title{
Sosialisasi dan Pengembangan Potensi Desa melalui Pelaksanaan Perilaku Hidup Bersih dan Sehat sebagai Upaya Pencegahan Penyebaran Virus COVID-19
}

\author{
Sylva Flora Ninta Tarigan', Tri Septian Maksum² \\ ${ }^{1,2}$ Fakultas Olahraga dan Kesehatan, Universitas Negeri Gorontalo, Jl. Jend. \\ Sudirman No.6, Dulalowo Tim., Kota Tengah, Kota Gorontalo, Gorontalo 96128, \\ Indonesia \\ email: floraninta@gmail.com, triseptian@ung.ac.id
}

\begin{abstract}
The cases of COVID-19 in Gorontalo Province, especially in North Gorontalo District, are still increasing and have not yet reached the peak of the pandemic, so the most effective effort currently carried out is implementing Clean and Healthy Living Behavior (PHBS). Community service activities are carried out in Tudi Village, Monano District, North Gorontalo District, with the aim of: (1) creating public awareness in preventing the spread of the COVID-19 virus by socializing the application of PHBS, and (2) developing village potential through training on the application of PHBS, including making cloth masks and natural hand sanitizers. The target to be achieved is to increase community participation in PHBS, where people already know, want, and are able to independently make natural hand sanitizer and cloth masks. The activity stages include preparation and provision, as well as implementation in the field. The results of the implementation of these community service activities are: (1) increased public understanding of PHBS efforts, and (2) the community has the skills and independence in making natural hand sanitizers and cloth masks, so that it becomes an effort to suppress or control cases of illness and death due to COVID-19.
\end{abstract}

Keywords : COVID-19; PHBS; Mask; Hand Sanitizer

\begin{abstract}
Abstrak
Kasus COVID-19 di Provinsi Gorontalo khususnya di Kabupaten Gorontalo Utara masih terus mengalami peningkatan dan belum mencapai puncak pandemi, sehingga upaya yang paling efektif dilakukan saat ini adalah menerapkan Perilaku Hidup Bersih dan Sehat (PHBS). Kegiatan pengabdian kepada masyarakat dilakukan di Desa Tudi Kecamatan Monano Kabupaten Gorontalo Utara, dengan tujuan untuk: (1) menciptakan kepedulian masyarakat dalam mencegah penyebaran virus COVID-19 dengan cara sosialisasi penerapan PHBS, dan (2) mengembangkan potensi desa melalui pelatihan penerapan PHBS, meliputi pembuatan masker kain dan hand sanitizer alami. Target yang hendak dicapai adalah meningkatnya partisipasi masyarakat dalam ber-PHBS, dimana masyarakat sudah tahu, mau, dan mampu membuat masker kain dan hand sanitizer alami secara mandiri. Tahapan kegiatan meliputi persiapan dan pembekalan, serta pelaksanaannya di lapangan. Hasil pelaksanaan kegiatan pengabdian kepada masyarakat ini adalah: (1) meningkatnya pemahaman masyarakat tentang upaya PHBS, dan (2) masyarakat telah memiliki
\end{abstract}


keterampilan dan kemandirian dalam membuat masker kain dan hand sanitizer alami, sehingga menjadi upaya dalam menekan/mengendalikan kasus kesakitan dan kematian akibat COVID-19.

Kata Kunci : COVID-19; PHBS; Masker; Hand Sanitizer

(C) 2020 Sylva Flora Ninta Tarigan, Tri Septian Maksum

Under the license CC BY-SA 4.0

Correspondence author: Sylva Flora Ninta Tarigan, floraninta@gmai.com,

PENDAHULUAN

Gorontalo, Indonesia

Coronavirus Diseases 2019 (COVID-19) merupakan suatu penyakit yang disebabkan oleh strain coronavirus baru (SARS-CoV-2) yang muncul di Wuhan, Hubei, Cina pada Desember 2019. Penyakit ini sebelumnya dikenal dengan sebutan 2019 novel coronavirus (2019nCoV) (WHO, 2020c), yang kemudian diresmikan oleh WHO pada tanggal 11 Februari 2020 dengan istilah COVID-19 (WHO, 2020f), dan beralih status dari epidemi ke pandemi pada tanggal 11 Maret 2020 (WHO, 2020e). Pandemi global COVID-19 sendiri sampai dengan tanggal 20 April 2020 telah menyebar ke 213 negara/territorial (WHO, 2020a).

COVID-19 mirip dengan influenza (Gorbalenya et al, 2020; Lin et al, 2020), yang tanda dan gejalanya biasanya meliputi demam, sakit kepala, dan batuk. Penularan terjadi melalui percikan air saat batuk atau bersin(droplet) dan virus ini menginfeksi manusia ketika droplet tersebut dihirup atau disentuh, sehingga akan menempel pada selaput lendir mata, mulut, hidung, dan saluran napas termasuk paru-paru (Susilo et al, 2020).

Total kasus COVID-19 di Gorontalo sampai dengan 11 Agustus 2020, adalah 1617 kasus, dirawat 369 kasus, 1207 kasus sembuh, dan 41 kasus meninggal. Dari angka tersebut, khusus untuk Kabupaten 
Gorontalo Utara dilaporkan total kasus sebanyak 119, 40 kasus dirawat, 75 kasus sembuh, dan 4 kasus meninggal (Dinas Kesehatan Provinsi Gorontalo, 2020). Dari data tersebut, maka penularan masih terus terjadi, dan belum ada indikasi mencapai puncak pandemi. Oleh karena itu, upaya yang perlu dilakukan saat ini adalah menerapkan Perilaku Hidup Bersih dan Sehat (PHBS) dan selalu mematuhi anjuran pemerintah terkait protokol kesehatan, seperti memakai masker, mencuci tangan dengan sabun pada air mengalir atau menggunakan hand sanitizer, dan menjaga jarak. Dampak pandemi yang tak terkendali ini, membuat masyarakat melakukan panic buying terhadap kebutuhan pokok dan alat kesehatan, seperti masker dan hand sanitizer, sehingga ketersediaan barang tersebut menjadi langka dan mahal.

Berdasarkan permasalah di atas, maka perlu dilakukan kegiatan pengabdian kepada masyarakat tentang sosialisasi dan pengembangan potensi desa melalui pelaksanaan perilaku hidup bersih dan sehat sebagai upaya pencegahan penyebaran virus COVID-19. Kegiatan pengabdian kepada masyarakat dilakukan di Desa Tudi Kecamatan Monano Kabupaten Gorontalo Utara, dengan tujuan untuk: (1) menciptakan kepedulian masyarakat dalam mencegah penyebaran virus COVID-19 dengan cara sosialisasi penerapan PHBS, dan (2) mengembangkan potensi desa melalui pelatihan penerapan PHBS, meliputi pembuatan masker kain dan hand sanitizer alami.

\section{METODE PELAKSANAAN}

Tahapan kegiatan pengabdian kepada masyarakat ini meliputi persiapan dan pembekalan, serta pelaksanaan kegiatan. Tahap 
persiapan dan pembekalan meliputi penyiapan materi sosialisasi serta alat dan bahan yang diperlukan untuk kegiatan pelatihan pembuatan masker kain dan hand sanitizer alami. Selanjutnya untuk tahap pelaksanaan, meliputi (1) observasi lapangan untuk menganalisis masalah yang dihadapi masyarakat Desa Tudi Kecamatan Monano Kabupaten Gorontalo Utara selama pandemi COVID-19, (2) persiapan program berupa penyusunan jadwal kegiatan yang disepakati bersama dengan masyarakat, (3) sosialisasi tentang penerapan PHBS yang dilakukan menggunakan metode ceramah dan diskusi secara offline, dan (4) pelatihan pembuatan masker kain dari bahan katun dan hand sanitizer alami dari bahan ekstrak daun sirih dan jeruk nipis yang juga dilakukan secara offline.

\section{HASIL DAN PEMBAHASAN}

Pandemi virus COVID-19 telah menyebabkan terganggunya kondisi sosial dan ekonomi masyarakat. Beberapa kegiatan yang seharusnya diikuti oleh orang banyak harus ditunda terlebih dahulu guna menekan angka penyebaran kasus. Penerapan PHBS senantiasa disosialisasikan untuk meningkatkan imunitas tubuh manusia. Salah satu contoh PHBS yang disosialisasikan oleh pemerintah adalah gerakan cuci tangan pakai sabun di air bersih dan mengalir (Ginting et al, 2020). Cara ini terbukti efektif dalam membunuh virus yang menempel pada tangan, namun akan terasa kurang efektif ketika berada di tempat yang tidak tersedia air. Oleh karena itu, penggunaan hand sanitizer sebagai pembersih tangan menjadi solusi dalam hal ini. Selain itu, pemerintah juga menganjurkan untuk menggunakan alat pelindung diri seperti masker saat keluar beraktivitas (Armiani 
et al, 2020). Namun akibat harga masker medis yang kurang terjangkau bagi masyarakat menyebabkan mereka beralih ke masker dengan bahan dasar kain yang bisa dipakai secara berulang kali.

Kegiatan pengabdian kepada masyarakat melalui sosialisasi tentang penerapan PHBS serta pelatihan pembuatan masker kain dari bahan katun dan hand sanitizer alami dari bahan ekstrak daun sirih dan jeruk nipis telah dilaksanakan pada hari Sabtu, 26 September 2020 bertempat di Sanggar Seni Desa Tudi. Tujuan kegiatan ini adalah untuk meningkatkan pemahaman masyarakat tentang upaya PHBS serta keterampilan dan kemandirian masyarakat dalam mengembangkan potensi desa dalam upaya menekan penyebaran virus COVID-19, sehingga dapat mengendalikan kasus kesakitan dan kematian akibat COVID-19.

Kegiatan sosialisasi tentang penerapan PHBS dilakukan melalui undangan yang dibantu oleh Pemerintah Desa Tudi untuk dapat mengumpulkan masyarakat setempat. Namun demikian, protokol kesehatan tetap diperhatikan seperti mencuci tangan dengan sabun sebelum masuk ruangan, menggunakan masker, dan tetap menjaga jarak aman minimal 1 meter. Kegiatan sosialisasi ini dihadiri oleh perwakilan masing-masing dusun yang ada di Desa Tudi. Keberhasilan kegiatan ini ditandai dengan antusias masyarakat yang tinggi mulai dari awal hingga akhir kegiatan sosialisasi.

Kegiatan pelatihan pembuatan masker kain diawali dengan pemutaran video tutorial pembuatan masker berbahan dasar kain katun, yang terdiri atas 3 lapisan sesuai dengan anjuran Kementerian Kesehatan RI. Setelah itu, dilanjutkan dengan mempraktikkannya 
dengan cara membuat kelompok-kelompok kecil yang didampingi oleh mahasiswa. Bentuk masker dirancang agar dapat rapat di bagian hidung, pipi, dan dagu pemakainya. Kebocoran udara yang masuk dan keluar tanpa tersaring dapat disebabkan oleh ukuran dan bentuk masker yang salah. Teknik yang digunakan dalam pembuatan masker ini adalah teknik jelujur menggunakan jahitan tangan sehingga semua orang dapat melakukannya dengan mandiri di rumah, tanpa kendala ketidaktersediaan mesin jahit. Penggunaan masker kain ini berbeda dengan masker medis, yakni hanya boleh digunakan sampai 4 jam, dan setelah itu langsung dicuci dan diganti dengan masker kain yang baru. Keunggulan dari masker ini yaitu bahan yang mudah didapat dan terjangkau dari segi biaya. Keberhasilan kegiatan ini ditandai dengan masyarakat yang telah terampil dalam membuat masker kain secara mandiri.

Kegiatan pelatihan pembuatan hand sanitizer ini dilakukan dengan menggunakan bahan alami yang tersedia di Desa Tudi yakni ekstrak daun sirih $15 \%$ dan jeruk nipis $8 \%$. Proses pembuatannya sangat praktis, dapat dilakukan sendiri di rumah, dan tidak mengeluarkan biaya yang mahal. Khasiat ekstrak daun sirih 15\% sama efektifnya dengan alkohol dalam membunuh virus dan bakteri yang menempel di tangan. Oleh karena hand sanitizer ini tidak menggunakan alkohol dan bahan pengawet lainnya sehingga ketahanan produk hanya berlangsung 4-7 hari. Keberhasilan kegiatan ini ditandai dengan masyarakat yang telah terampil dalam membuat hand sanitizer alami secara mandiri.

Pelatihan pembuatan masker kain dan hand sanitizer alami diharapkan bisa menjadi salah satu usaha kreatif di masa pandemi COVID-19. Dengan semakin tingginya permintaan akan masker dan 
hand sanitizer, diharapkan muncul wirausahawan baru di Desa Tudi yang menghasilkan produk ini, baik untuk kebutuhan masyarakat Desa Tudi atau dapat pula diperjualbelikan, sehingga akan meningkatkan pendapatan masyarakat Desa Tudi. Oleh karena keterbatasan ruang dalam pelaksanaan kegiatan, maka diharapkan bagi anggota masyarakat yang hadir kiranya dapat meneruskan informasi yang diperoleh saat kegiatan berlangsung kepada anggota masyarakat lain.

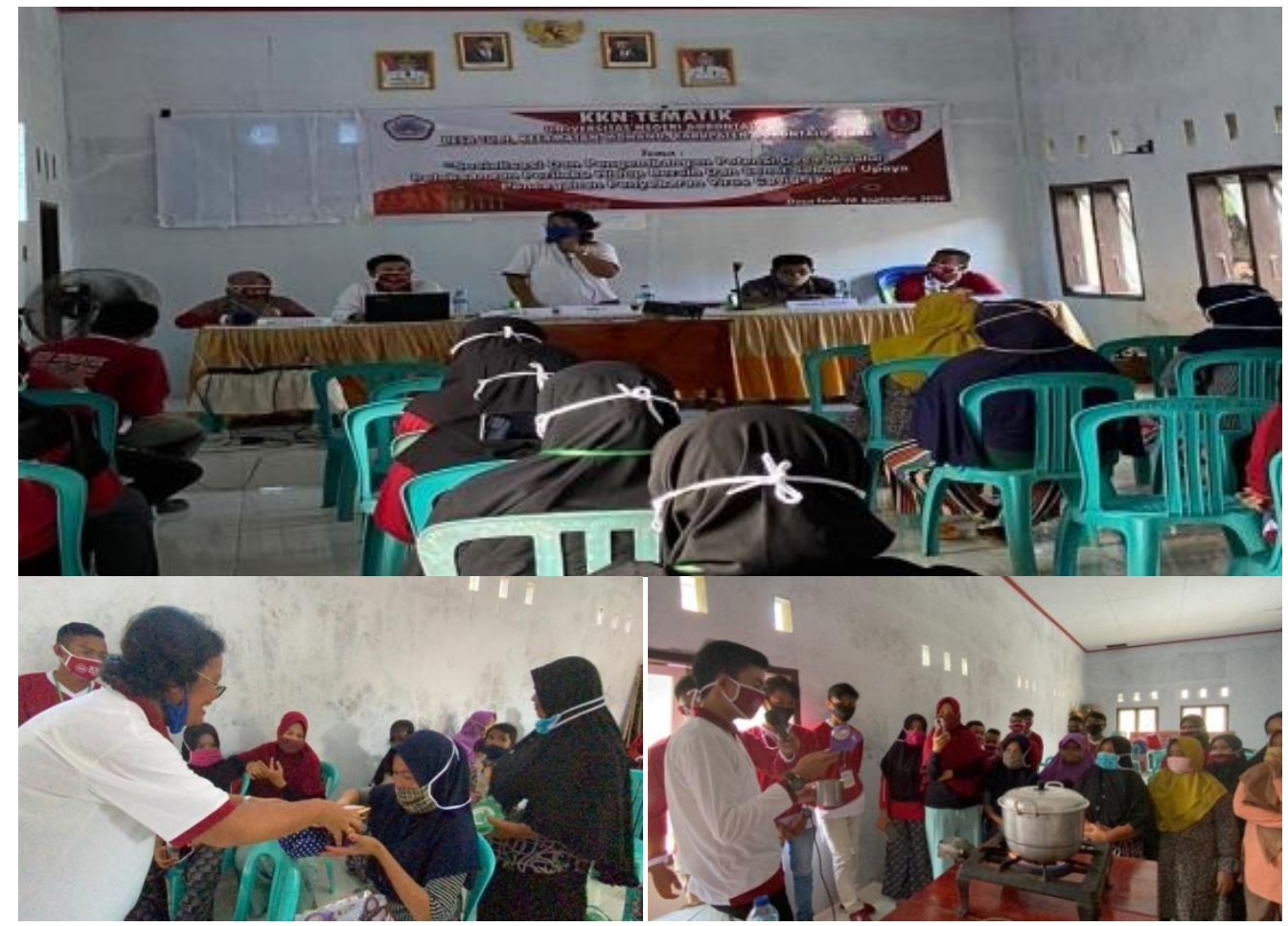

Gambar 1. Sosialisasi dan Pelatihan Pembuatan Masker Kain dan Hand Sanitizer Alami

\section{KESIMPULAN}

Kegiatan pengabdian kepada masyarakat berupa sosialisasi PHBS dan pelatihan pembuatan masker kain dan hand sanitizer alami 
yang dilakukan di Desa Tudi Kecamatan Monano Kabupaten Gorontalo Utara berjalan dengan lancar dan sesuai target yang hendak dicapai. Pemahaman masyarakat tentang PHBS menjadi meningkat serta masyarakat telah terampil secara mandiri dalam mengembangkan potensi desa yang ada di tengah pandemi COVID-19. Hal ini menjadi upaya dalam menekan penyebaran virus COVID-19, sehingga dapat mengendalikan kasus kesakitan dan kematian akibat COVID-19, kembali beraktivitas dalam tatanan kehidupan/kebiasaan baru (new normal life). Hasil dari kegiatan ini diharapkan bisa menjadi salah satu usaha kreatif masyarakat Desa Tudi di masa pandemi COVID-19, sehingga dapat meningkatkan ekonomi masyarakat akibat terdampak COVID-19.

\section{UCAPAN TERIMA KASIH}

Penulis mengucapkan terima kasih kepada Lembaga Penelitian dan Pengabdian kepada Masyarakat (LPPM) Universitas Negeri Gorontalo yang telah memberi dukungan dana dalam pelaksanaan pengabdian. Tak lupa pula ucapan terima kasih kepada Pemerintah Desa Tudi Kecamatan Monano Kabupaten Gorontalo Utara yang telah memfasilitasi terlaksananya kegiatan pengabdian ini.

\section{REFERENSI}

Armiani et al. 2020. "Pelatihan Pembuatan Masker Sebagai Upaya Antisipasi Penyebaran Covid-19 di Desa Anyar Kabupaten Lombok Utara”. Jurnal Pengabdian UNDIKMA 1(1): 22-27.

Dinas Kesehatan Provinsi Gorontalo. 2020. “Jumlah Terpapar Covid-19 $\mathrm{Di}$ Gorontalo". Available at: 
https://dinkes.gorontaloprov.go.id/covid-19/. (Accessed on 12 Agustus 2020).

Ginting et al. 2020. "Pemberdayaan Masyarakat Desa Jungsemi di Masa Pandemi Covid 19 Melalui Pelatihan Pembuatan Hand Sanitizer dan Pelindung Wajah". Indonesian Journal of Empowerment and Community Services 1(1): 21-27.

Gorbalenya et al. 2020. "The species Severe acute respiratory syndrome-related coronavirus: classifying 2019-nCoV and naming it SARS-CoV-2". Nature Microbiology 5 (March). doi:10.1038/s41564-020-0695-z.

Lin et al. 2020. "Hypothesis for potential pathogenesis of SARS-CoV-2 infection-a review of immune changes in patients with viral pneumonia, emerging microbes \& infections". Taylor \& Francis. Doi:10.1080/22221751.2020.1746199.

Susilo et al. 2020. "Coronavirus Disease 2019: Tinjauan Literatur Terkini Coronavirus Disease 2019 : Review of Current Literatures". Jurnal Penyakit Dalam Indonesia 7(1): 45-67.

WHO. 2020a. "Coronavirus (Covid-19) Dashboard (New Website)". Available at: https://who.sprinklr.com/\# (Accessed on 12 Agustus 2020).

WHO. 2020c. "Naming the coronavirus disease (COVID-19) and the virus that causes it". Available at: https://www.who.int/emergencies/diseases/novelcoronavirus2019/technical-guidance/naming-the-coronavirus-disease-(covid2019)-and-the-virus-that-causes-it (Accessed on 12 Agustus 2020).

WHO. 2020e. "WHO Director-General's opening remarks at the media briefing on COVID-19 - 11 March 2020". Available at: https://www.who.int/dg/speeches/detail/who-director-general-sopeningremarks-at-the-media-briefing-on-covid-19---11-march2020 (Accessed on 12 Agustus 2020).

WHO. 2020f. "WHO Director-General's remarks at the media briefing on2019-nCoV on 11 February 2020". Available at: https://www.who.int/dg/speeches/detail/who-director-general-s- 
remarksat-the-media-briefing-on-2019-ncov-on-11-february-2020 (Accessed on 12 Agustus 2020). 